\title{
Learning From Personality A.H. Nasution: Starting from Glory to Getting Out of the Political and Military Stage in Indonesia
}

\author{
Samudra Eka Cipta*) \\ Department of History Education, Faculty of Social Sciences Education, \\ Universitas Pendidikan Indonesia, Bandung, 40154, West Java, Indonesia.
}

Received: 2020-01-21; Accepted: 2020-03-27; Published: 2020-04-30

\begin{abstract}
General Abdul Haris Nasution is a national hero who has been educated from the military. Starting from being the Commander of the KNIL (Dutch East Indies Army) to becoming Minister of Internal Defense. Nasution once served as Commander of the Siliwangi Military Command. Nasution was very true of the military world. Nasution had been the target of murder from the PKI (Indonesian Communist Party). However, Nasution escaped death until he suffered minor injuries and legs. Nasution was also entrusted as Chair of the MPRS (Provisional People's Consultative Assembly). When Soekarno was confronted by Mahmilub (Extraordinary Court) by reading Pel-Nakwasara (Complementary Nakwasara) which contained about the pledoi for his defense efforts related to the G $30 S$ (September 30, 1965). Nasution, who was then chairman of the MPRS, refused the pledoi and immediately replaced Suharto as president. The New Order period lasted for 32 years Nasution's fate became increasingly tragic. Nasution was withdrawn from military service by Soeharto when it was proven in the Petition Objection 50 which was signed by several former generals and officers loyal to Sukarno to criticize Suharto's policies at that time. This researchs uses historical research methods, in this study aims to study more deeply about the figure of Abdul Haris Nasution began his career as a military until the end of the tragic as a retired soldier. The problem in this research is 1) How is the initial gait of A.H. Nasution? 2) How was Abdul Haris Nasution's role in defending Indonesia's independence 3) how Nasution's relationship with Sukarno and Suharto.
\end{abstract}

Keywords: Nasution; Militarism; Indonesian; Politics; History

How to Cite: Cipta, S.E., (2020). Learning From Personality A.H. Nasution: Starting from Glory to Getting Out of the Political and Military Stage in Indonesia. Journal of Contemporary Governance and Public Policy, 1(1), 18-26.

Permalink/DOI: https://doi.org/10.46507/jcgpp.v1i1.6 


\section{Introduction}

The man born in Kotanopan, December 3, 1918, in the early days of his career had begun to enter the military world. Since the Dutch East Indies opened military education for the Bumiputera group, then what is known as K.N.I.L (Koninklijk Nederlands-Indische Leger), then Nasution registered and got his military knowledge in Bandung together with T.B. Simatupang. During his military education, Nasution was always active and obedient to his superiors. This also led Nasution to become a middle officer at K.N.I.L because of his superiors' trust in Nasution's performance while he was a member of K.N.I.L. In the period of Japanese occupation, when founding PETA (Defender of the Motherland) by Dai Nippon's Army, Nasution's status was announced from the military world. Nasution had long been friends with Sukarno when both of them were in Bandung. They always carry out discussions regarding the problems faced by the Nation. For Nasution, Sukarno was a teacher and the formation of a young Nasution character. Young Nasution always read Sukarno's works about his nationalism ideas and often explained to his friends. After Indonesian Independence, Nasution returned to active in the military and joined the TKR (People's Security Army). In 1946 Nasution was appointed as the Siliwangi Division III Commander. The hardest task experienced by Nasution at the beginning of his tenure as Pangdam was to banish Dutch Police Operations (or Dutch Military Aggression I) when the Dutch were accompanied by NICA trying to control strategic areas in Bandung. Another task faced by Nasution was trying to reduce the separatist movement initiated by Raden Soerija
Kertalegawa in the formation of the Pasundan State from 1947-1949 (Kuswandi, 2015).

Nasution's career in the military field was increasing, he was appointed as Deputy Commander of the TKR. Together with Sudirman Nasution and his forces tried to quell the rebellion of the Indonesian Communist Party in Madiun in 1948. The operation launched by Siliwangi succeeded in killing Muso while other PKI leaders, including DN Aidit, fled

In the New Order era, Soehartu was sacked from the military when he and other former officers signed ' ' 50 Petitions '. Abdul Haris Nasution was then blamed for the incidence of 50 petitions and the new Order Govt made him a house prisoner. During the custody of the house Abdul Nasution did not get the lack of treatment of the rights as a retired military official had not fulfilled by the new Order government. But because of the attitudes and personality of Abud Haris Nasution was very patient in his various political trials during the post-retired TNI (Mulyana, 2013, p. 85).

\section{Research Methods}

In the methodology of writing, the writer uses a qualitative research approach by doing descriptive on various sources of literature using scientific articles and books as a source of comparison and also uses a historical methodological approach consisting of heuristics, criticism, interpretation, explanation, and historiography (Sjamsuddin, 2015, p. 30). Historical research method is a method or method used as a guide in conducting research into historical events and their problems. In other words, the method of historical research is an instrument to reconstruct historical events (history as past actuality) into history as 
stories (history as written). Within the scope of Historical Sciences, the research method is called the historical method.

\section{Result and Disscusion}

\section{Tidal Relationship A.H. Nasution with Sukarno}

Although Nasution had previously had good relations with Sukarno, it was possible that the friendship relations between the two would sometimes worsen but sometimes it also improved. The initial tension between Nasution and Sukarno when in an incident on October 17, 1952, a battalion was mobilized by Nasution layered with steel kaveleri and directed a cannon towards the front of the palace. The action was originally only 5,000 people and then increased to 30,000 people. The action carried out by Nasution was not intended to make a coup attempt against Sukarno but to dissolve the DPRS. Starting from the motion of Manai Sophiaan, Secretary General of the PNI, who argued that the DPRS has the right to interfere in ABRI's internal problems. To President Soekarno, Colonel AH Nasution demanded to dissolve the DPRS. According to Nasution, the DPRS was too meddling in internal TNI matters, especially in leadership matters within the Army. The President rejected Nasution's proposal. The reason is that the President has no authority to dissolve the DPRS. Despite this, Soekarno did not want to be a dictator. Another consideration, the masses who demanded the dissolution of Parliament, according to the president, were only a handful of Jakartans and did not represent the overall desires of the people.

However, Nasution's

subordinate, Bambang Supeno rejected what was proposed by Manai Sophiaan also urged Nasution to be immediately appointed as KSAD (Army Chief of Staff). Apparently, Manai Sophiaan's proposal received tremendous support, especially from NU, Parkindo, the Catholic Party, PKI, Parindra, and the Labor Party, and Murba. In fact, Ignasius Kasimo proposed the formation of a counter motion idea in the Ministry of Defense (Leni, 2013, p. 33). The essence of what parliamentary support was initiated by Manai Sophiaan was aimed at improving the structure of the military sector and realizing efforts to keep the military generals obedient and obedient to Sukarno. Nasution, too, did not quietly immediately immediately argue with Sukarno. Nasution still insisted that it was time for the army to get involved in determining the direction of state policy. For him, the army is not only needed when the country is in a war situation. These are the initial seeds of the concept of the ABRI Dwi Function that Nasution initiated. This idea (the Dwi Function of the Armed Forces) was then carried out in the New Order period. Sukarno understood the matter, but he was already disappointed with Nasution's method. In December 1952, at the behest of the president of the Attorney General examining Nasution and TB Simatupang. Both are proven guilty. Since then Nasution has no longer become a military and his status has been deactivated. After the dismissal of Nasution as Army Chief of Staff (Army Chief of Staff) in 1952, Nasution later established the IPKI Party (Pancasila Support Association). IPKI was formed by Nasution as a participant in the 1955 elections. Nasution's formation of the IPKI was possible without reason but because of Soekanrno's efforts to eliminate military influence on the political scene. However, the results of the 1955 General Election were still very far below Masyumi, PNI, and 
PKI. Their relationship then improved when Soekarno recalled what Nasution had sacrificed with his Siliwang troops to defend Indonesia's independence in the Age of Physical Revolution. The President then issued a Presidential Decree of July 5, 1959 and appointed Nasution as Minister of Defense and Security. However, Nasution's position as Minister of Defense has another meaning for 'kicking up' what Sukarno did with Nasution. But Soekarno-Nasution's relations deteriorated again when the PKI began to play fully in the Indonesian political arena. Nasution did not like this, so he took distance from Soekarno and continued to criticize (Anderson, 2017, p. 127).

The climax was that in 1964 Nasution embraced his former colleague from the Siliwangi Division to launch an operation aimed at freeing the influence of the PKI in the military body in which the operation was understood as 'Operation Budi' (Sundhaussen, 1986, p. 290). On the other hand, Nasution was also at odds with Ahmad Yani because he was considered too close to Sukarno, even though they were both anti-PKI. Soekarno, who had bad experiences with Nasution, finally "eliminated" Nasution by making him ABRI Chief of Staff. This position made Nasution, like a toothless tiger, appear fierce but had no power because he did not have the command to move the troops (Firdaus, 2016, p. 7)

\section{Nasution and the September 30 Movement}

Like those who had been supported before, that Nasution really hated the PKI. This triggered the PKI's strong reaction to an attack on his house. As with other generals who were attacked, the PKI carried out a method using a very large force. About one hundred people involved in this movement were led by Untung.
Incidentally, Nasution's house was very close to Dr.'s house. Johannes Leimena a Sukarno loyalist. There had been a fight between Untung's army and the house guards of Dr. J. Leimenna. One guard (member of the police) was killed after a fight with troops under Untung's pipeline. The purpose of the attack on the guards of the house of J. Leimenna was that when Nasution was about to escape from his house when he was invaded by Untung's troops, there was no one from J. Leimena's house guard to protect Nasution. The trucks almost partially carried almost all of the Cakrabirawa troops and a number of the Infantry I Brigades and 454 Battalions, and several members of their Pemuda Rakyat were recruited to ambush Nasution's house. The Nasution family woke up when he heard the sound of the door opening. Mrs. Nasution came out to find out what had happened. The troops then tried to break down and search to find Nasution. Mardiah Nasution's younger brother tried to save his brother and incidentally at that time Mardiah was carrying Princess Sulung Nasution Ade Irma Soerjani Nasution. However, without mercy then a person from Cakrabirawa named Hargyono shot Mardiah and killed Ade Irma Nasution. At the same time, Mrs. Nasution secretly brought her husband behind the yard to take refuge in an Iraqi Embassy home. Nasution was shot by Untung's troops who were on guard from the outside but thought the troops were just a shadow remembering the incident at night to make Nasution's leg fractured. Because he did not succeed in arresting Nasution, the troops fled and left Ade Irma's body full of blood. After the incident a few months later in 1966, Nasution asked Soekarno regarding the September 30th Movement. Previously, Nasution had been appointed by Sukarno as the 
MPRS mandate as well as a reaction to what was demanded by his students through his 'Tritura', Sukarno immediately formed a new cabinet on July 25, 1965 by forming the 'Ampera' I. Cabinet Sukarno after the year 1965 as if it began to lose its influence, many ministers in the Dwikorra Cabinet indicated " PKI " were later arrested. One of them is Soebandrio, a Minister of Foreign Relations. But the most shocking thing after the event was "The September 30 Movement' is the arrest of Air Force Marshal Omar Dani among military officials. For Suharto who was then serving as the Pangkostrad (Commander of the Army Strategic Command) the arrest of Omar Dani because Halim (the Republic of Indonesia Air Force headquarters) had been used as the headquarters of the treason movement carried out by the PKI. Nevertheless, Nasution actually did not know anything about the arrest of Soeharto's ministers and military officials. Because of the truth, Nasution's position when "The September 30 Movement' served as Minister of Defense and did not hold the authority for the arrest (Fathurrohman, 2018, p. 66).

On January 10, 1967 at the end of his position as president Sukarno read a written report containing his pledoi on his involvement in the "September 30, 1965 Movement" before the MPRS (Provisional Consultative Assembly) session, which was later known as Pelengkap Nawaksara. read by Soekarnokemudian then strongly opposed by Nasution along with the character " Anti-Sukarno " and Nasution as the Mandate of the MPRS immediately removed Sukarno as president for life and replaced Suharto as Indonesian President at that time (Wanandi, 2017, p. 127).

\section{Abdul Haris Nasution's policy on politics towards the transition of New Order}

Abdul Haris Nasution was appointed Minister of Defence by President Sukarno on 10 July 1959 in the work cabinet composition III, which he had compiled by Sukarno. As long as the Minister of Defence there are at least two policies done by AH. Nasution, the first ratified the War Emergency Act or in the language of his uncle was known as Staat van Oorlog en Beleg (sob). This law was formed given the prestige of parliamentary democracy, given that time the occurrence of various turmoil in the area of the region that is about to separate from Indonesia such as in Ambon with the separative movement of the RMS (Republic of South Maluku), Rebellion DI'TII in Kalimantan, Sulawesi, and Aceh, and the rebellion of the PRRI/Permesta as a result of the long This legislation officially formed a guided democracy government for the military to support the policy considering that time the military considers that with the establishment of a new political style will provide opportunities for the military to engage in the politics of Indonesia. Ah. Nasution was given the belief to be Minister of Defence. However, some parties judge that Nasution's appointment as Minister of Defence was Sukarno's political step in eliminating his political opponents. Nasution was appointed Minister of Ministers but had no influence whatsoever in carrying out his various habits in the political sphere. Nasution's figure was merely regarded as symbolic of Sukarno's form of political politics.

Secondly, Nasution formulated the political policy of ' ' The Middle Way ' ', the policy was strongly supported by the military because the policy provided full military opportunities to be involved in 
practical politics. Nasution always campaigned the policy to officers and the ranks of the military. According to Salim Said (2003) said that the concept initiated by Nasution is a concept as defensive against the influence of communism in Indonesia which has become an enemy for the TNI and the NU (Nahdatul Ulama). The September 1965 Movement event decided Nasution to apply the policy. The army gained a lot of sympathy from the community after the killing of several generals and made the strong adoption of the concept. His political concept is also known as the concept of the dual function of ABRI. When Nasution was the speaker at a military seminar in Bandung in 1966 which was attended by all officers from various divisions in Indonesia for the introduction of the idea. But the political implementation of road Tenagh conducted by Nasution also participated in every effort and activities of society in the field of ideology, politics, economics, social, and Culture (Notosusanto, 1970). The idea of the concept actually gives enough channels to soldiers not as organizations, but as individuals (all military members) who become exponent in the formation of political forces in Indonesia, by participating in formulating and executing state policies and placing at the position of executive institutions and legislative states (Church, 1988, p. 24).

Thirdly, Nasution was appointed chairman of the Provisional People's Consultative Assembly (MPRS), as long as the chairman of the MPR AH. Nasution was a trial witness of the Movement event 30 September 1965. Nasution listened to Sukarno's testimony of the incident. Nasution then opened a special session of MPRS. The trial discussed the complement of the Nawaksara, the resolution and memorandum of DPR-GR, confirmation of decision dated 20 February 1967, juridical fact concerning Sukarno's relationship with G. 30. S/PKI. In the meantime, General Suharto as the ruling holder of MPRS No. IX/1966 gave a report to the MPRS special hearing about the relationship between President Sukarno and G. 30. S 1965 the political point of President Sukarno's fault was to remain confident that the PKI could be united with Pancasila, the general Suharto. (DTS). The trial also succeeded Suharto as president and was automatically discharged from the President (Dwipayana \& Sjamsuddin, 2003, p. 165).

\section{Nasution in New Order Era.}

Suharto came to power, then the influence of Nasution had begun to be forgotten. Slowly Nasution began to be removed from the military world. The presence of General Djuhartono and Ali Moertopo as Suharto's 'accomplice' exacerbated Nasution's career in the military. Until finally Nasution was retired disrespectfully from the TNI. Unlike Soekarno's time who always insisted when he was disturbed. However, in the New Order era when he felt threatened by his military career Nasution continued to struggle even though the influence of Soeharto's generals 'helpers' was far stronger than he was. In 1971 in the early days of the Soeharto Government General Djuhartono, who was the general of Soeharto's loyalties, formed a Joint Secretariat of the Working Group (before becoming a political party). The aim of the formation of the Golkar Joint Secretariat was to support all kinds of Suharto's policies. At the same time Soeharto carried out a policy in which political parties must be fused. Soeharto for the formation of Golkar in addition to strengthening the consolidation of 
the New Order's power between Soeharto-Military-Civil Servants, Golkar was formed to stop various kinds of divisions between each political party related to ideology and political party orientation. Especially when the events of September 1965 Soeharto knew very well that the incident was not repeated again by limiting the number of political parties and political participants to maintain security stability at that time (Jenkins, 2010, p. 250). However, the establishment of the Golkar Joint Secretariat actually has the duties and functions of political parties. At the beginning of the formation of Golkar there was a great deal of opposition, especially among the military forces of the 45 's.For the opposition, especially former exofficers, 45 Golkar Joint Secretariat has committed irregularities in political matters. On May 5, 1980 army officers made a petition containing criticism of Soeharto's policies in which Nasution was involved. The petition is known as 'Petition 50' 'not only Nasution but other names involved in the petition are: Ali Sadikin, M. Jasin, Hoegeng Imam Santoso, A.Y. Mokoginta, and Mohammad Nazir. Other generals who participated and were involved in the signing had another motive, namely that not all officers of the Army45 who also fought for Indonesian Independence during the Defending of Indonesian Independence in 1945-1950 could become members of the political elite especially in the "core group". More and more ABRI officers (Indonesian Armed Forces) and civilian politicians became disillusioned with the Soeharto regime, because all important political positions were monopolized by close people personally with the President. The less satisfied generals are often dubbed "Barisan Sickness" . Among them may be jealous because they feel more merit than some members of the "core group", or have not received the expected material rewards. Seeing the insubordination carried out by general officers, Suharto then approached the officers. Starting from being given a warning even the arrest and dismissal of ABRI as felt by General TNI Pranoto Reksosamodra was captured by Suharto and Nasution was dishonorably dismissed from ABRI. In addition, after the signing of the Petition Nasution often received treatment that was not worn by Soeharto's personal aides. This was felt by Nasution when he wanted to address Adam Malik's body, Nasution was pulled out of the room on the grounds that former Vice-President Umar Wirahadikusuma would put Adam Malik's body in check. Not only that, the less weary actions felt by Nasution led to the unilateral termination of the water channel to his house to force him to make his own well to get water. Nevertheless, General Nasution was not a vindictive person, he was very persistent in facing all forms of trials approaching the end of his life. Nasution as a retired military officer, in the end he founded a youth organization namely "Pemuda Pancasila". the goal of the establishment of the Pancasila Youth organization was initially built to increase the sense of nationalism and love of the homeland (Makruf, 2019, p. 33).

\section{Conclusion}

During his lifetime Nasution continued to experience various trials as "Political Victims" starting from Sukarno's time after the October 1952 incident but Nasution at the insistence of Muhammad Hatta asked Sukarno that Nasution immediately return to serve as KSAD (Army Chief of Staff). Hatta succeeded, Nasution 
was later appointed by Sukarno to become Minister of Defense. Then, Nasution, who was initially very contradictory to Sukarno, then fully supported Sukarno's custom in the era of Leadership Democracy. There was another purpose for the appointment of Nasution by Sukarno to be Defense Minister namely Sukarnno wanted to 'kick up' Nasution so as not to mess with what was done by Sukannrno. This was proven when the G30 S (September 30 Movement) event in which a conflict between the Army and the PKI (Indonesian Communist Party) took place, Nasution, who was then Minister of Defense, could do nothing about the incident. In fact, Sukarno commissioned Suharto, who was then the Pangkostrad (Commander of the Army Strategic Command) without notifying or assigning Nasution directly in dealing with treason events carried out by the Indonesian Communist Party. The political atrocities felt by Nasution continued until the New Order period. Nasution was disliked by Suharto because Nasution was considered by Suharto to be the mastermind behind the 'Signatory of the 50' Petition' which was actually just a form of Nasution's criticism of Suharto's performance as president at that time. However, Suharto's response considered it a movement of treason or coup to overthrow him as president. As a result, Nasution was dismissed from the Army disrespectfully by Suharto. Not only that, as a consequence of what he did to Suharto, even Nasution did not get any state facilities or even allowances. Nevertheless Nasution was a patient figure even though political atrocities continued to befall him from Sukarno's time to Suharto's Period.

\section{Acknowledgments}

The author would like to thank to Universitas Pendidikan Indonesia for research support and writing this article.

\section{References}

Anderson. (2017). Kudeta 1 Oktober 1965: Sebuah Analisis Awal. Yogyakarta: Gading Press.

Church, H. (1988). The Army and Politics in Indonesia. New York: Cornell University Press.

Dwipayana, \& Sjamsuddin, N. (2003). Jejak Langkah Pak Harto 01 Oktober 1965-27 Maret 1968. Jakarta: CV Kharisma Bunda.

Fathurrohman, E. (2018). Peranan Jenderal AH Nasution Dalam Peristiwa 17 Oktober 1952. UIN Sultan Maulana Hasanuddin Banten.

Firdaus, D. W. (2016). Kebijakan Dwifungsi Abri Dalam Perluasan Peran Militer Di Bidang Sosial Politik Tahun 1966-1998. Jurnal UPI: Bandung, 1-13.

Jenkins, D. (2010). Soeharto dan Barisan Jendral Sakit Hati. Depok: Komunitas Bambu Press.

Kuswandi, K. (2015). Pengaruh Perang Kemerdekaan II Terhadap Pengakuan Kedaulatan RI Tanggal 27 December $1949 . \quad J u r n a l$ Artefak, 3(2), 207-220.

Leni, N. (2013). Keterlibatan Militer dalam Kancah Politik di Indonesia. Jurnal Tapis: Jurnal Teropong Aspirasi Politik Islam, 9(1), 31-45.

Makruf, A. (2019). Peranan Abdul Haris Nasution dalam peristiwa Bandung Lautan Api tahun 1945-1946. Universitas Siliwangi. 
Mulyana, A. (2013). Nasionalisme dan Militerisme: Ideologisasi Historiografi Buku Teks Pelajaran Sejarah SMA. Paramita: Historical Studies Journal, 23(1).

Notosusanto, N. (1970). The dual function of the Indonesian Armed Forces, especially since 1966. Jakarta: Dept. of Defence \& Security, Centre for Armed Forces History.
Said, S. (2003). Dari Gestapu ke Reformasi. Bandung: Mizan.

Sjamsuddin. (2015). Metodologi Sejarah. Yogyakarta: Ombak.

Sundhaussen. (1986). Politik Militer Indnesia 1945-1967: Menuju Dwi Fungsi ABRI. Jakarta: LP3ES.

Wanandi, J. (2017). Menyibak Tabir Orde Baru. Jakarta: Kompas Media Nusantara.

(C) 2020 by Autors. Submitted for possible open access publication under the terms and conditions of the Creative Commons Attribution (CC BY SA) license (https://creativecommons.org/licenses/by-sa/3.0/). 